FILOZOFIA

Roč. 76, 2021, č. 3

DOI: https://doi.org/10.31577/filozofia.2021.76.3.3

\title{
FOUCAULT: OD MIKROFYZIKY MOCI KU GUVERNMENTALITE ${ }^{1}$
}

\author{
VLADISLAV SUVÁK, Prešovská univerzita v Prešove, Filozofická fakulta, Prešov, SR \\ SUVÁK, V.: Foucault: From the Microphysics of Power to the Governmentality \\ FILOZOFIA, 76, 2021, No 3, pp. $195-208$

\begin{abstract}
The aim of the paper is to outline the development of later Foucault's thought concerning the study of power. Foucault often changed his approaches to power, and this investigation changed his thinking about power. At the beginning he dealt with the microphysics of power, later he focused on the study of governmentality as the art of governing, which includes both the ways of governing and the modes of subjectivation. Problematiziation of governmentality allowed Foucault to link two major topics he had addressed in the last years of his life,
\end{abstract} \\ politics and ethics.
}

Keywords: Michel Foucault - Power - Governmentality - Subject - Politics - Ethics

\section{Úvod}

Zámerom tohto článku je načrtnút’ myšlienkovú cestu, ktorou prešiel Michel Foucault v poslednej dekáde svojho života, ked' chcel študovat' moc. Nepôjde teda o konfrontáciu Foucaultovho premýšl’ania s inými vplyvnými koncepciami moci, ale o priblíženie zápasov, ktoré musel vybojovat' sám so sebou, ked' chcel pochopit', ako sa uplatňuje moc. Dnes máme k dispozícii väčšiu čast' textov a prednášok z tohto obdobia, preto môžeme sledovat' krok za krokom, ako Foucault menil svoje prístupy k štúdiu moci a ako menilo toto štúdium jeho myslenie. Zjednodušene by sme mohli povedat', že Foucaultova cesta viedla od mikrofyziky moci k dejinám guvernmentality. Foucault postupne dospel k presvedčeniu, že moc nemôžeme študovat', ak do nej nezahrnieme aj techniky riadenia samého seba a druhých.

Ked’že ide o pomerne komplikovanú tému, nebudem sa zaoberat' výhradami voči Foucaultovmu chápaniu moci zo strany jeho potenciálnych kritikov, či už minulých alebo súčasných. ${ }^{2}$ Zameriam sa na to, čo všetko musel Foucault zahrnút' do

\footnotetext{
${ }^{1}$ Za kritické prečítanie rukopisnej verzie článku d’akujem L’ubomírovi Dunajovi a Ulrichovi Wollnerovi.

2 Týmito diskusiami sa zaoberajú viaceré štúdie uverejnené v časopise Filozofia, napr. Buraj (2010), Buraj, Palenčárová (2015).
} 
svojho skúmania moci. Na začiatku to boli represívne mechanizmy, na konci subjekt a spôsoby, ako sa vzt'ahuje $\mathrm{k}$ sebe, respektíve ako vstupuje do hier pravdy a nepravdy. Práve tento vzt'ah - medzi subjektom, mocou a pravdou - je podl'a môjho názoru dôležitý aj pre súčasné pokusy o vymedzenie moci. ${ }^{3}$

\section{Mikrofyzika moci}

Viaceré médiá označili Foucaulta za „,teoretika moci.“ On sám sa proti tomu ohradzoval, lebo nikdy nechcel vypracovat' teóriu moci (Foucault 2000g). Na jeho obranu treba povedat', že si nekladie otázky typu, „čo je moc?“, ale zaoberá sa konkrétnymi, časovo ohraničenými dejinami moderných inštitúcií (klinika, blázinec, väzenie, škola), ktoré sú organizované a riadené mocenskými mechanizmami, lebo chce pochopit', aký je ich vzt'ah k príslušným typom vedenia (medicína, psychiatria, kriminológia, pedagogika), pre ktoré sú tieto inštitúcie ,podmienkami možnosti““. Navyše Foucaultove stratégie skúmania moci sa obmieňajú a spolu s nimi sa mení aj samo vnímanie moci.

Záujem o štúdium moci umocnili vo Francúzsku májové udalostí v roku 1968. $\mathrm{Na}$ konci šest'desiatych rokov si viacerí francúzski intelektuáli museli priznat', že nevedia vysvetlit' moc tak, aby objasnili procesy, ktoré nastali po študentských nepokojoch. Foucault v jednom rozhovore vysvetl'uje, že l'avica ani pravica nedokázali objasnit' mechanizmy moci - táto úloha sa podl'a neho pred rokom 1968 ani nemohla naplnit', lebo by sa musela opriet' o každodenné zápasy najširších vrstiev, v ktorých sa zviditel'ňuje konkrétna povaha moci; zároveň je potrebné, aby sme ju ponechali mimo pol’a politických analýz (Foucault 2000d, 117). Na základe tohto vyjadrenia sa zdá, že možnost' študovat' moc z neteoretickej perspektívy sa naplno otvorila až vd'aka udalostiam z roku 1968.

Výsledkom náhlych a spontánnych študentských nepokojov, ktoré prerástli do generálneho štrajku, bolo vytvorenie novej vlády, tá sa však paradoxne nelíšila od tej starej. Nespočetné diskusie o tom, čo sa vlastne odohralo v máji a júni 1968, vyústili do pochybností, či vôbec prebehla nejaká revolúcia. Boli vzbúrenci revolucionármi, ktorí zvrhli štátnu moc, tú moc, ktorá ešte nedávno tvrdo potlačila alžírsky pokus o štátny prevrat? Alebo sa podobali skôr účastníkom gréckych Kronií a rímskych Saturnálií, ktorí oslavovali dočasný „neporiadok“ (désordre) v očakávaní návratu starého sociálneho poriadku (l'ordre social)? (Balandier 1970) Nebolo to skôr tak, že revoltujúci dav sa ocitol v úlohe otroka, ktorý zaujme na jeden deň miesto panovníka,

${ }^{3}$ Foucaultovo chápanie subjektu (cez subjektivácie), moci (cez guvernmentalitu) a pravdy (cez veridikciu a alethurgiu) umožňuje aj nové prístupy k interpretáciám sokratovskej literatúry. Dobrým príkladom je štúdia Kurta Lampeho, ktorá demonštruje, že sokratovské texty, ktoré boli v porovnaní s Platónovými dialógmi považované za marginálne, sa môžu ukázat' ako zaujímavé a dôležité, ak pri nich uplatníme foucaultovské čítanie (Lampe 2015, 61 -81). 
môže sa oddávat' orgiám prístupným iba panovníkovi, ale na sklonku dňa ho čaká povraz alebo kríž? Uvol’nená moc sa v priebehu rituálu ukáže ako nepravá a vyvolá túžbu po návrate starej panovníckej moci. Májové udalosti odkryli podla viacerých intelektuálov dvojznačnost' moci - na jednej strane jej krehkost' a na druhej strane jej neotrasitel'nost'. Preto si začali klást' otázky, aké by si predtým nepoložili: Prečo je moc raz odmietaná a inokedy prijímaná? Prečo sa každá revolúcia končí reštauráciou poriadku? (Descombes 1995)

Už pred májovými udalost’ami sa objavovali diskusie o vzt'ahu medzi teóriou a praxou, ktoré mali svoj politický aspekt (spájali sa s úlohou intelektuálov sympatizujúcich s marxizmom alebo maoizmom). Po roku 1968 viaceré známe osobnosti odpovedali na potrebu praxe tým, že sa pokúsili vypracovat' politickú analýzu túžby, teda prepojit' Marxa s Freudom.

V dialógu s Michelom Foucaultom v marci 1972 Gilles Deleuze hovorí o potrebe nanovo vymedzit' vzt'ah medzi teóriou a praxou: Tento vzt'ah sme vysvetl'ovali cez proces totalizácie; na prax sme sa dívali ako na uplatnenie teórie, na jej dôsledok, alebo sme jej pripisovali dôležitú úlohu inšpirátorky pre budúce teoretické formy. Dnes - hovorí Deleuze - si kladieme otázku fragmentárne: teória sa viaže vždy na určité ohraničené pole a uplatňuje sa $\mathrm{v}$ oblasti, ktorá je od neho viac či menej vzdialená; prax je súborom prenosov $\mathrm{z}$ jedného teoretického bodu do druhého a teória je zase prenosom z jednej praxe do druhej. Žiadna teória sa nemôže rozvíjat' bez toho, aby nenarazila na nejakú stenu, a prax je tým, čo musí túto stenu prerazit'. Nakoniec Deleuze konštatuje, že reprezentácia v tradičnom zmysle už neexistuje (teoretizujúci intelektuál nie je subjektom reprezentujúcim vedomie), existuje len konanie, teoretické alebo praktické, ktoré slúži formou prenosov (Foucault 1972). Foucault súhlasí s Deleuzom, že teória stratila totalizujúci charakter, že má miestny a regionálny význam. Úlohou intelektuála nie je zaujat' miesto v čele nejakej skupiny a vyslovit' jej potláčané pravdy, ale bojovat' proti formám moci, ktoré ho transformujú na jej predmet a nástroj v oblasti „vedenia“, ,pravdy“, „vedomia“ a „diskurzu“ (Foucault 1994a, II, 308). Moc je záhadná vec - viditel'ná i neviditel'ná, prítomná i skrytá, všadeprítomná. Ani Freud, ani Marx, ani žiadne teórie vlády, ani tradičné analýzy jej mechanizmov neuspokojujú našu túžbu porozumiet' moci. Myšlienka „vládnucej triedy“ (narážka na Sartra, Althusera a d’alších neomarxistov) nebola adekvátne formulovaná - doposial' nevieme, čo znamená „mat' nadvládu“ (dominer), „riadit““ (diriger), „vládnut"“ (gouverner) (Foucault 1994a, II, 313).

Deleuze a Foucault sa v diskusii odvolávajú na príklady z vlastných kníh, no ich dialóg sa nesie v značne zovšeobecňujúcom tóne (obaja hovoria o „teórii“, „praxi“, „moci“), ktorý sa neskôr vytratí z Foucaultovho slovníka (bude hovorit' o konkrétnych „,nediskurzívnych praktikách“, „represívnych praktikách“, „mocenských vzt’ahoch“ 
atd'.). No zmení sa najmä jeho pohl’ad na úlohu intelektuála ako toho, kto sa štylizuje do roly toho, kto napráva spoločenské poriadky, alebo si aspoň nahovára, že má určitý vplyv na zmeny v spoločnosti. V rozhovore z roku 1984 Foucault spomína na svoje študentské začiatky, na nekonečné diskusie o povahe marxizmu, ktoré mali v samom strede problém prepojenia teórie s praxou. S odstupom času si myslí, že najbezprostrednejším spôsobom, ako chápat' tento vzt'ah, je rozvíjat' ho priamo vo vlastnej praxi (Foucault 1991).

V januári 1976 Foucault zahajuje prednáškový kurz Spoločnost' treba bránit'. Chce zavrišit' štúdium mechanizmov moci, ktoré majú represívny charakter. V druhej prednáške uvažuje o sérii analýz mocenských vztahov, ktoré by vychádzali z modelu vojny. Plánuje pokračovat' v skúmaní moci, ktorému sa venoval ostatných pät rokov, ale zároveň dáva moc do úzkeho vzt’ahu s pravdou (Foucault 2005). Foucault uprednostňuje vo vztahu k moci otázku ,ako?“ pred otázkou „čo?“. Zaujímajú ho účinky vyvolané mocenskými vzt'ahmi, nie moc ako substancia. Nezaujíma sa o to, odkial' sa moc berie, ale ako sa praktizuje. Aj vd'aka tomu sa zbavuje tendencie dávat' moci výlučne negatívne významy, teda stavat' ju do protikladu so slobodou alebo pravdou. V roku 1979 píše článok pre Le Monde, v ktorom zdôrazňuje, že aj ked' sa výkon moci spája vždy s určitým nebezpečenstvom, neznamená to, že moc je vo svojej povahe zlom, ale že mechanizmy moci sú nekonečné - čo však neznamená, že moc je všemocná (Foucault 1994b). ${ }^{4}$ O niečo neskôr hovorí, že výkon moci by sme mali chápat' ako súbor konaní pôsobiacich na možné konania, ako to, čo podnecuje, ovplyvňuje, zvádza, ul'ahčuje alebo st’ažuje, rozširuje alebo obmedzuje, robí viac alebo menej pravdepodobným, iba v extrémnych prípadoch bráni alebo zakazuje absolútne - vždy je to spôsob konania pôsobiaci na konajúce subjekty alebo subjekty schopné konat' (Foucault 1982). Moc prikazuje, obmedzuje, zakazuje, ale aby to mohla robit', musí podnecovat', ul'ahčovat', umožňovat' vykonávanie určitých činností. Mali by sme raz a navždy prestat's opismi účinkov moci negatívnou terminológiou. Moc v skutočnosti nevylučuje, ale produkuje realitu; moc produkuje oblasti predmetov a rituály pravdy. „Z tejto produkcie vychádza indivíduum a poznanie, ktoré sa o ňom dá nadobudnút"“ (Foucault 2000a, 195). Slová, ktoré vyznievajú nietzscheovsky, sú predzvest'ou zmien $\mathrm{v}$ prístupoch k moci. Podl'a Deleuza sa to odráža v trojici téz, ktoré Foucault vzt’ahuje

\footnotetext{
${ }^{4} \mathrm{~V}$ tom istom čase vedie Pierre Boncenne rozhovor s Foucaultom, v ktorom chce vyjasnit' chápanie moci (Foucault 1985, 355 - 363). Foucault zdôrazňuje, že pravda je forma moci, čo vyplýva z myšlienkovej tradície Západu, ktorá si kladie otázky typu: Prečo sme pripútaní k pravde? Prečo skôr k pravde ako ku lži? Prečo skôr k pravde ako k mýtu? Prečo skôr k pravde ako ku klamu? Namiesto toho, aby sme sa snažili zistit', čo je pravda ako protiklad omylu, bolo by zaujímavé zaoberat' sa otázkou, ktorú kladie Nietzsche: Ako došlo k tomu, že v našich spoločnostiach nadobudla „pravda“ takú podobu, že sme sa vd’aka nej dostali do jej područia?
} 
k moci (Deleuze 1996, 102): Moc nie je represívna, lebo podnecuje, navádza, produkuje; moc je v ovel’a väčšej miere praktikovaná ako vlastnená; moc preniká všetkými silami, teda ovládanými aj vládnucimi.

V kurze Spoločnost' treba bránit' Foucault pripomína tradičnú otázku politického myslenia: Ako môže pravdivý diskurz určit' právne medze moci? Foucaultova otázka znie inak: Aký typ moci je schopný produkovat' pravdivostné diskurzy, ktoré nadobúdajú v našej spoločnosti tak mocné účinky? (Foucault 2005, 38)

Politický význam Foucaultových prác, ich rastúci vplyv na aktivistov (najmä talianskych a nemeckých), je témou rozhovoru s Alessandrom Fontanom a Pasqualem Pasquinom (Foucault 2000d). Foucault v ňom analyzuje prístupy l'avice aj pravice $\mathrm{k}$ moci a vysvetl'uje, prečo ju nevie uchopit' ani jedna, ani druhá strana. V závere rozhovoru sa vracia k vzt'ahu medzi mocou a pravdou: Mali by sme pochopit', že pravda nie je niečo, čo by bolo $\mathrm{v}$ protiklade $\mathrm{k}$ moci - nie je to privilégium tých, ktorí sa dokázali oslobodit'. Pravda je vec, ktorá patrí do tohto sveta: vzniká len vd’aka rôznorodým formám obmedzení a vyvoláva opakujúce sa účinky moci. Každá spoločnost' má svoju „všeobecnú politiku pravdy“, mechanizmy umožňujúce človeku rozlišovat' medzi pravdivými a nepravdivými výpoved’ami, určité prostriedky, ktorými je každý človek postihovaný, určité techniky a procedúry, poskytujúce hodnotu nadobúdaniu pravdy atd'. Problémom nie je to, ako by sme mohli emancipovat' pravdu od systému moci (to je chiméra, lebo pravda je vždy súčast'ou moci), ale to, ako by sme mali oddelit' moc pravdy od foriem sociálnej, ekonomickej a kultúrnej hegemónie, uprostred ktorých operuje. Na záver Foucault poznamenáva: „,... politickou otázkou nie je omyl, klam, odcudzené vedomie alebo ideológia - je ňou samotná pravda. Preto je pre nás taký dôležitý Nietzsche“ (Foucault 2000d, 133).5

\section{Stopy guvernmentality}

Predzvest' zmien v prístupoch k moci môžeme zachytit' v prednáškovom kurze $B e z-$ pečnost', teritórium, populácia. Posun ohlasuje téma guvernmentality, ktorou sa Foucault dovtedy nezaoberal. Štvrtá prednáška je prvým náčrtom nového skúmania. Z dobových reakcií vieme, že auditórium Collège de France bolo zmätené (Defert 1994, 52 - 53), lebo guvernmentalita vybočovala z rámca tém, ktorým sa Foucault venoval (represívne mechanizmy moci, biopolitika, sexualita atd'.). S odstupom času však vidíme, že práve táto téma otvára priestor pre nové otázky, ktoré si Foucault začne klást' na začiatku osemdesiatych rokov.

\footnotetext{
${ }^{5}$ Foucault sa nechce zaoberat' bytostnou povahou pravdy, ale tým, ako sa pravda prejavuje (Foucault 1994c, 445). Pravda je forma moci (Foucault 1985).
} 
Výraz „guvernmentalita“ (gouvernementalité) je novotvar (vel’mi škaredý, ako poznamenáva Foucault), ktorý zahŕňa širšie pole významov, než naznačuje spredmetnené adjektívum gouvernemental („týkajúci sa vlády“) (Foucault 2004b, 119). Čo si máme predstavit' pod guvernmentalitou? V prvom rade je to nové chápanie spôsobu vládnutia (gouvernement) na konci šestnásteho a na začiatku sedemnásteho storočia. V tomto období sa rozvíja nová racionalita štátu, „štátny záujem“ (raison d’État), ktorý sa transformuje zo stredovekých prístupov k vládnutiu, a rozvinie sa do komplexného umenia vládnut' - jeho základným princípom je racionalita zachovania štátu.

V prednáške o guvernmentalite Foucault vysvetl'uje, že antické a stredoveké texty poskytovali vládcom rady, ako sa majú správat', ako majú uplatňovat' moc, aby ich rešpektovali poddaní. Od konca šestnásteho storočia sa objavujú texty, ktoré sa zameriavajú na „umenie vládnut““ (art de gouverner), napríklad na umenie vládnut' sám sebe (čo súvisí s renesanciou stoicizmu), ale takisto na umenie vládnut' det'om, rodine, alebo na umenie vládnut' štátu. Otázka, ktorú si kladie množstvo vzdelancov od šestnásteho storočia, znie: „Ako treba riadit', kým, do akej miery, kvôli akým účelom, akými metódami?"“(Foucault 2004b, 92) Množstvo spisov z tohto obdobia tematizuje politickú formu vlády, pričom ich spoločným znakom je pretrvávajúce odmietanie, či dokonca odpor voči Machiavelliho Vladárovi (Foucault 2004b, 93).

V závere prednášky sa Foucault obracia k samému pojmu „guvernmentalita“ a načrtáva budúci projekt jej skúmania. Pod guvernmentalitou by sme si mali predstavit' tri veci: 1) určitý súbor sformovaný inštitúciami, procedúrami, reflexiami a analýzami, kalkuláciami a taktikami, ktorý dovol'uje uplatňovat' vel'mi zvláštnu, no vel'mi komplexnú moc, na ktorú je zameraná populácia; moc, ktorá je hlavnou formou vedenia pre politickú ekonómiu a podstatným technickým nástrojom pre aparáty bezpečnosti (dispositifs de la sécurité); 2) je to tendencia sily, ktorá zaujala počas dlhého trvania Západu čelné postavenie medzi inými typmi moci (ako suverenita, disciplína atd'.) a umožnila rozvoj série zvláštnych aparátov vládnutia a série rôznych vedení; 3 ) výsledok procesu, ktorým sa guvernmentalizoval stredoveký štát spravodlivosti a v priebehu pätnásteho až šestnásteho storočia sa začal menit’ na štát administratívny. ${ }^{6}$ Foucault hovorí o dejinách guvernmentality štátu v šestnástom až osemnástom storočí, no zároveň dodáva, že aj my sme súčast’ou tohto dejinného procesu, v ktorom sa umenie vládnut' stáva jednotiacim prvkom racionality.

Guvernmentalita - zameraná na spôsoby, ako vládnut' (opät' je tu priorita „ako“ pred „,̌̌o“) - má vonkajškový aj vnútorný charakter, čo umožňuje skúmat' praktiky, techniky, politické technológie, ktoré používa umenie vládnutia, a to nielen ako číre

${ }^{6}$ Zrod moderného štátu vidí Foucault ako zvláštnu, až démonickú hru, ktorú rozohralo krest'anské pastierstvo, či ako kombináciu dvoch hier (obec-občan, pastier-stádo), ktorej prvkami sú život, smrt', pravda, poslušnost', jednotlivci a seba-vymedzenie (Foucault 1996, 172 - 173). 
prostriedky na dosahovanie ciel'ov (Foucault 2004b, 113). V d'alších rokoch sa Foucault sústredí na skúmanie guvernmentality v štyroch obdobiach a štyroch oblastiach: Najprv to bude staroveké chápanie vládnutia a jeho porovnanie s pastierskou mocou raného krest'anstva (tretie až štvrté storočie). Neskôr to bude zrodenie politickej racionality a nástup raného moderného štátu (šestnáste až sedemnáste storočie). Potom to bude vznik liberalizmu v osemnástom storočí a nakoniec povojnové formy neoliberalizmu v USA, Západnom Nemecku a Francúzsku.

Ked' sa pozrieme na Foucaultovo zhrnutie z roku 1978, pochopíme, že guvernmentalita nie je to isté, čo „vláda“, „riadenie“, „vedenie“, aj ked’ s týmito pojmami úzko súvisí. Nemali by sme ju stotožňovat' ani so suverenitou alebo disciplínou, hoci je pre ňu príznačná určitá tendencia sily. Guvernmentalita vzniká ako výsledok zložitého dejinného procesu a etabluje sa ako umenie, ktoré je schopné vytvárat' a uplatňovat’ techniky účinnej vlády. Guvernmentalita znamená, že prax vládnutia je nielen predstavitel'ná, ale aj prakticky uskutočnitel'ná tými, ktorí ju uplatňujú, a tými, na ktorých sa uplatňuje (Gordon 1991).

Čo naznačuje téma guvernmentality v kontexte Foucaultových predošlých analýz? Ked' vyjdeme z predpokladu, že ich modus operandi tvoria vzt’ahy medzi skúsenost’ami (šialenstva, choroby, zločinu, sexuality), formami vedenia (psychiatria, lekárstvo, kriminológia, sexuológia, psychológia) a rôznymi technikami moci (vykonávanými v psychiatrických, trestných a d’alších inštitúciách), tak guvernmentalita otvára väčší priestor na skúmanie ,individualizujúcej moci“(Foucault 1996, 155). Foucault sa chce zaoberat' rozvojom techník moci, ktoré sa zameriavajú na jednotlivcov a sú určené na ich nepretržité ovládanie. Zároveň zdôrazňuje, že dejiny guvernmentality by mali byt' - podobne ako jeho predošlé skúmania - dejinami vzt'ahov, aké udržiava myslenie s pravdou, čiže dejinami myslenia ako myslenia pravdy (Foucault 2000f, 109).

Vo februári 1979 vystúpi Foucault na Stanfordovej univerzite s dvoma prednáškami nazvanými Omnes et Singulatim: Ku kritike politického rozumu, v ktorých sa pokúša o zhrnutie svojho dvojročného štúdia guvernmentality. Poslucháčom hovorí, že nevie, ako by mal opísat' svoj výskum, ale aj napriek počiatočným rozpakom formuluje niekol'ko zásadných postulátov, ktoré vyplývajú z kritiky politického rozumu (Foucault 1996, 192 - 194):

1) Moc nie je substancia. Nemali by sme v nej hl'adat žiadnu tajomnú prirodzenost', ktorú by bolo treba odkryt' či odhalit'. Moc je určitý typ vzt'ahov medzi jednotlivcami. Tieto vzt'ahy majú zvláštnu povahu, lebo aj ked' sa pridružujú k výmene, produkcii a komunikácii, v konečnom dôsledku s nimi nemajú nič spoločné. Charakteristickým znakom moci je to, že niektorí l'udia môžu vo väčšej alebo menšej miere vplývat' na správanie iných l'udí, ale nikdy 
ich nemôžu donútit’ k úplnej zmene správania. Neexistuje moc, ktorá sa nedá odmietnut'.

2) Vláda jedných nad druhými predpokladá určitú racionalitu. Moc, ktorá vládne iba inštrumentálnym násilím, sa nedokáže udržat'.

3) Odpor voči moci si nevystačí s kritikou inštitúcií a odhal'ovaním násilia, ktoré spôsobili alebo použili. Musí sa spochybnit’ forma racionality, na ktorú sa moc odvoláva. Ak chceme kritizovat' moc uplatňovanú na bláznoch, nevystačíme si s kritikou psychiatrie ako mocenskej inštitúcie - musíme sa zamerat' na to, ako sa racionalizujú vzt’ahy moci.

4) Naša civilizácia rozvinula najzložitejší systém vedenia a najsofistikovanejšiu štruktúru moci. Štát bol od svojho vzniku na začiatku modernej doby jednou z najpozoruhodnejších a najobávanejších foriem l'udskej vlády. Štát je od samého začiatku totalizujúci a zároveň individualizujúci. Žiadne oslobodenie však nemôže vzíst' z útoku na tieto dva dôsledky politickej racionality - zaútočit' treba na samé korene racionality.

Oproti prvému náčrtu z roku 1978 dochádza v nasledujúcich rokoch $\mathrm{k}$ posunu vo vymedzení guvernmentality. Foucault už nedáva do vzájomných súvislostí iba bezpečnost', politickú ekonómiu a štát, teda nezaoberá sa iba politickou stránkou guvernmentality, ale čoraz viac premýšla o spôsoboch, ktorými človek riadi vládu nad druhými - všíma si samo vládnutie ako určitú mriežku zamýšlaných vzt'ahov moci, ktoré treba analyzovat' (Foucault, 2004a, 191 - 192). Sústred'uje sa na doménu vzt'ahov vytvárajúcich moc. A zaujíma sa takisto o racionalitu guvernmentality, ako to môžeme vidiet' v prednáškach $O$ vláde nad živými, ktoré sa venujú technikám a procedúram zacieleným na riadenie správania l'udí (Foucault 2012, 318). Foucault má na zreteli predovšetkým vládu nad det’mi, vládu nad dušami, ale takisto sa zaujíma o vedenie domácnosti, vedenie štátu a vedenie samého seba. ${ }^{7}$

Foucaultovým zámerom je vypracovanie konceptu vládnutia nad druhými pomocou pravdy (Foucault, 2012; Foucault, 2004a). Ide o nový projekt. V kurze $O$ vláde nad živými hovorí o dvoch rozdielnych, aj ked’ na seba nadväzujúcich posunoch: Prvý od pojmu dominantnej ideológie k vedeniu-moci. Druhý od vedenia-moci k pojmu vlády pomocou pravdy. V zhrnutí kurzu $O$ vláde nad živými sa dotýka aj zmien v prístupe k dejinám guvernmentality (Foucault, 1994a, IV, 125 - 129). Chce skúmat procedúry zamerané na riadenie správania l'udí, ktoré sa rozvíjajú v ranokrest’anských kláštorných rádoch, lebo techniky priznania a dozoru nad vedomím tvoria dôležitú

\footnotetext{
${ }^{7}$ Poznamenajme, že viacerí interpreti vzt’ahujú guvernmentalitu výlučne k vedeniu štátu (Revel, 2002, 38 - 39), alebo ju dávajú do užších súvislosti s politickými a sociálnymi problémami (Gordon 1991, 1 - 51; Jessop 2007, 34 - 40; Bröckling, Krasmann, Lemke 2011).
} 
súčast' guvernmentality vytvorenej pastierskou mocou. Významným aspektom vlády nad druhými sa stáva alethurgia (,manifestácia pravdy“), v ktorej nejde iba o to, aby subjekt povedal pravdu, ale aby ju vyslovil o sebe - musí vyjavit' pravdu o svojich chybách, túžbach, o stave svojej duše. Takýto typ guvernmentality vyžaduje od človeka poslušnost', a zároveň manifestáciu toho, kým je, vo forme priznania. Súčast'ou Foucaultových analýz nie je teda iba politická racionalita, ale aj otázka, ako boli v našich kultúrach ustanovené vzt’ahy medzi ovládaním l’udí, manifestáciou pravdy vo forme subjektivity a spásou pre jednotlivcov aj pre celé spoločenstvá? (Foucault 2012, 79)

Ďalšie dva kurzy v rokoch 1980 - 1982 (Subjektivita a pravda a Hermeneutika subjektu) ukazujú guvernmentalitu z perspektívy vedenia samého seba. V zhrnutí kurzu Subjektivita a pravda Foucault ukazuje príklady takýchto guvernmentalít: pedagogika, duchovné vedenie, poradenstvo $\mathrm{v}$ oblasti správania alebo predpisy modelov pre život (Foucault 1989). Analýzy týchto foriem guvernmentality zarad'uje do dejín subjektivity - subjektivity, ktorú by sme mali chápat' ako výsledok procesov subjektivácií, ktorým sa jednotlivci podriad'ujú alebo ktoré uplatňujú sami na sebe. Inými slovami, Foucaulta zaujíma vzájomné pôsobenie vytvárané dvoma typmi techník technikami ovládania, ktorými jednotlivci pôsobia navzájom na seba, a technikami seba samého (techniques de soi), ktorými subjekt pôsobí sám na seba. Dlhý čas sa zaoberal technikami ovládania, aké sa uplatňujú v blázincoch alebo vo väzeniach. Ibaže to je iba jedna stránka guvernmentality. Teraz sa chce venovat' technikám seba samého, ktoré tvoria d'alšiu stránku guvernmentality (Foucault 2016, 24).

Ovládanie l'udí by sme nemali stotožňovat's donucovaním l'udí robit' to, čo chce vládca - je to pohyblivá, mnohostranná rovnováha, v ktorej sa navzájom doplńajú a dostávajú do sporov rôzne techniky zabezpečujúce procesy, prostredníctvom ktorých sa ,ja“ utvára alebo mení za pomoci samého seba (Foucault 2016, 26). Ked' sa pozrieme na guvernmentalitu z hl'adiska strategického pol'a vzt'ahov moci, ktoré sú pohyblivé, premenlivé a zvratné, nevyhneme sa subjektu (Foucault 2001, 241 - 242). Preto treba analyzovat' nielen vzt'ahy jednotlivca k druhým, ale aj vzt’ah jednotlivca k sebe. Potrebujeme analyzovat' miesto, kde sa stretáva politika s etikou.

Foucault si uvedomuje, že vláda nad druhými predpokladá vládu nad sebou, že tieto dva typy vlády sa v našej kultúre navzájom podmieňujú. Vzt'ah $\mathrm{k}$ vlastnému ja sa v priebehu dejín vyvíja a mení už od antiky. Foucault preto začína systematicky čítat' texty krest'anských a grécko-rímskych autorov, ktoré človeku radia, ako sa má správat' - texty, ktoré sú praktické, a zároveň sú predmetom praxe, lebo boli vytvorené na to, aby si ich jednotlivci osvojovali, meditovali nad nimi, použivali ich. Tieto texty dnes zarad’ujeme medzi „etické“ “či „teologické“, ale v staroveku mali iný status, ktorý sa vysvetl'uje pomerne t’ažko. Pomocou týchto textov jednotlivci utvárali sami seba 
ako etické subjekty - pôsobili na seba, teda vykonávali zámerné operácie na svojich telách, dušiach, mysliach, konaniach a spôsoboch bytia s ciel'om dosiahnut' určitý stav št'astia, čistoty, múdrosti, spásy či nesmrtel’nosti. Každý, kto chcel ovládnut' svoj život, musel aktívne uplatňovat' určité súbory praktík, prostredníctvom ktorých sa pokúšal zmenit' sám seba.

$\mathrm{Na}$ začiatku osemdesiatych rokov sa menia Foucaultove analýzy guvernmentality. V tomto čase pripravuje do tlače druhý a tretí zväzok Dejín sexuality - od vydania prvého zväzku uplynulo niekol'ko rokov, zmenil sa jeho pohl'ad na moc, a on nevie, ako by nadviazal na pôvodný plán práce, načrtnutý vo Vôli $k$ vedeniu (1976). Nakoniec sa rozhodne vypracovat' nový projekt, $\mathrm{v}$ ktorom etické spôsoby vytvárania vztahu k sebe zohrávajú ovel’a dôležitejšiu úlohu ako ich postoje $\mathrm{k}$,sexualite“ určované vedeniami, ktoré sa $\mathrm{k}$ nej bezprostredne vzt’ahujú (lekárstvo, psychiatria, sexuológia atd'.), alebo systémami moci, ktoré predpisujú pravidlá pre jej výkon (trestná moc, disciplinárne úkony atd'.). V Predslove k druhému zväzku Dejín sexuality (Užívanie slastí) Foucault vysvetl'uje, čo všetko sa zmenilo v plánovanom projekte z jeho slov cítime určité obavy, aby nepredložil d’alšiu teoretickú štúdiu na tému „túžiaceho subjektu“. Uvedomuje si, že praktiky vytvárania vzt’ahu k sebe sa nedajú uchopit' teoreticky, pretože nezapadajú do tradičnej diferencie teórie a praxe. Foucault sa snaží dostat' na hranicu tejto diferencie, respektíve rád by ju úplne opustil, aby mohol vypracovat' kritickú genealógiu skúsenosti človeka s vlastnou sexualitou.

Čo sa mení vo Foucaultovom prístupe k subjektu z hl'adiska otázky moci? V jednom rozhovore to vysvetl'uje: „Ak hovorím pravdu o sebe samom, ako to aj robím, znamená to, že sa čiastočne konštituujem ako subjekt prostredníctvom istých mocenských vzt'ahov, ktoré sa uplatňujú na mňa a ktoré ja uplatňujem na iných“ (Foucault 2000g, 66). V procesoch sebautvárania zohráva najdôležitejšiu úlohu pravda, ku ktorej sa musí jednotlivec dopracovat', alebo si ju musí priznat', lebo len vo vzt'ahu k nej sa môže zmenit'. Posledné roky svojho života Foucault venuje vel'ké úsilie skúmaniu pravdy, najmä „pravdivému hovoreniu“ (gr. parrhésia) či „odvahe povedat' pravdu“. Chce napísat' knihu pre Editions du Seuil, ktorá by sa mala volat' rovnako ako jeho posledné kurzy na Collège de France: Vláda nad sebou a druhými. Kniha by mala prepojit' dve vel'ké oblasti, ktorými sa zaoberá od sedemdesiatych rokov: etiku a politiku. Nakoniec sa k písaniu nedostal. Zomrel náhle, uprostred práce. Množstvo tém, ktorým sa chcel venovat', zostalo nedokončených, poznáme iba ich hrubé obrysy, ale niet pochýb, že sa chcel vrátit' $k$ dejinám subjektivity a problematizovat' moderné prístupy k subjektu. Svedčia o tom viaceré rozhovory z toho obdobia. 


\section{Zhrnutie, ktoré nič neuzatvára}

Ked' pozorne sledujeme Foucaultove kroky na ceste od otázok moci k umeniu vládnut', zistíme, že oblast' guvernmentality tvoria všetky tri oblasti, ktorými sa Foucault zaoberal počas svojho života: „vedenie“, „moc“, „,subjekt“. Zároveň sa ukazuje, že guvernmentalita spája tému moci so subjektivitou, takže poskytuje určitý kl’úč k tomu, ako by sme mohli začlenit’ do dejín subjektivity genealogické skúmanie vedenia a moci.

Na guvernmentalitu sa na jednej strane môžeme dívat' ako na „umenie vládnut'“, ktoré uplatňuje rôzne mocenské techniky, zamerané na efektívne riadenie moderných spoločností. Na druhej strane guvernmentalita splýva s politickou racionalitou vd'aka nej sa rozvíjajú rôzne typy vedenia, ktoré sú zamerané na to, ako racionálne riadit' štát a zachovávat' funkčnost' tohto riadenia. V kontexte Foucaultových analýz zo sedemdesiatych rokov môžeme povedat', že vedenie a moc sú v guvernmentalite navzájom prepletené; jedno sa prejavuje prostredníctvom druhého.

Ked' sa pozrieme na umenie vládnut' $\mathrm{z}$ hl'adiska riadenia jednotlivcov, pochopíme, že toto umenie zahíňa nielen oblast' techník, ,ako ovládat' druhých“, ale aj oblast' techník, ,ako byt' ovládaný“, do ktorej patria techniky seba samého, teda techniky, ktoré uplatñuje subjekt $\mathrm{v}$ snahe ovládnut' sám seba. Vd’aka schopnosti ovládat' sám seba je subjekt otvorený voči možnosti nechat' sa ovládat' druhými. Práve prienik týchto dvoch oblastí tvorí guvernmentalitu (Foucault 2000h, 188). Preto musíme začlenit' do dejín umenia vládnut' spôsoby, ako jednotlivec pôsobí sám na seba prostredníctvom seba. Touto oblast'ou vládnutia sa Foucault intenzívne zaoberá v kurze Hermeneutika subjektu, pričom svoje skúmania poníma ako súčast' dejín subjektivity a rozvíja ich až do posledného kurzu Odvaha k pravde. Zlom, ktorý sa začína Hermeneutikou subjektu, tkvie v zmene perspektívy pri skúmaní guvernmentality: Foucault sa nechce venovat' genealogickému štúdiu politických systémov, ale sústred’uje sa na problematizáciu subjektu. Dokonca aj sám výraz „problematizácia“ naznačuje nový prístup $\mathrm{k}$ historickej práci, ktorá zahŕňa genealógiu i archeológiu, čiže dva Foucaultove prístupy $\mathrm{k}$ historickej práci (Foucault 2003, 18 -21).

V jednom rozhovore z roku 1984 Foucault vysvetluje, prečo sa guvernmentalita nezaobíde bez vzt’ahu subjektu k sebe samému: ,,... pojmom guvernmentality sa zameriavam na súbor praxí, ktorými sa dajú konštituovat', definovat', organizovat' a inštrumentalizovat' stratégie, akými sa indivíduá vo svojej slobode môžu na seba navzájom vzt'ahovat"“ (Foucault 2000c, 152-153). V tomto bode sa guvernmentalita týka slobody, či presnejšie povedané, týka sa možnosti slobody ako klúčovej témy moderného myslenia - témy, ktorá má politický aj etický rozmer: „Slobodné indivíduá sa pokúšajú kontrolovat', určovat' a vymedzovat' slobodu iných a na to majú $\mathrm{k}$ dispozícii isté nástroje na riadenie iných. Pravdaže, to všetko je založené na slobode, na vztahu 
k sebe a na vzt'ahu k inému. Ak sa však nepokúšate analyzovat' moc na základe slobody, stratégií a guvernmentality, ale na základe politickej inštitúcie, nevyhnutne budete subjekt vnímat' iba ako právny subjekt. Dostaneme subjekt, ktorý je alebo nie je obdarený právami a ktorému inštitúcia politickej spoločnosti dala alebo vzala práva: takto sme odkázaní na právnu koncepciu subjektu. Na druhej strane pojem guvernmentality podl'a mňa umožňuje zdôraznit' slobodu subjektu a vzt'ah k iným, teda to, čo je vlastným predmetom etiky“ (Foucault 2000c, 152 - 153).

Z tejto perspektívy sa ukazuje, že moc nemôžeme uchopit' cez kategórie práva, ale mali by sme ju pochopit' ako stratégiu, v ktorej zohráva právo iba jednu zo strategických možností. Slobodu môžeme mysliet' ako prax, ktorú uskutočňujú l'udia (konkrétni jednotlivci vo vzt’ahu ku konkrétnym jednotlivcom), a nie inštitúcie alebo zákony. V žiadnej inštitúcii, v žiadnom zákone nenájdeme ,záruku slobody.“ Foucault hovorí, že jedinou zárukou slobody je jej praktizovanie (Foucault 2000e, 32 - 33).

Takto vymedzená sloboda možno pôsobí nejasne. Mohli by sme povedat', že Foucault neprichádza s návrhmi na riešenie problémov, ale díva sa na ne cez rôzne genealogické perspektívy. To nám však nebráni pýtat’ sa, čo sa skrýva za pojmom „sloboda“, ked’ o ňom hovorí ako o vlastnom predmete etiky? Na otázku G. Rauleta Čo je dnešok? Foucault odpovedá, že charakterizovat', čo sme, nemožno cez nejakú jednoduchú tézu - mali by sme sledovat' línie nestálosti v dnešku, zachytávat', kde a ako to, čo je, môže prestat' byt' tým, čo je. Deskripciu treba robit' podl'a tohto druhu možnej fraktúry, ktorý otvára priestor slobode, chápaný ako priestor konkrétnej slobody, teda možnej transformácie (Foucault 2000g, 63). Slobodu by sme mohli vymedzit'v tomto kontexte ako „sociálnu prax“(Prozorov 2007, 5 - 6). Foucault v nej nehl'adá (na rozdiel od existenciálnych tendencií) l'udskú schopnost' a nepovažuje ju ani za podstatnú črtu sociálneho poriadku (preto sa nepýta, ktoré sociálne usporiadanie umožňuje najviac slobody). Slobodu dáva do vzt’ahu s (historicky premenlivými) možnost’ami jej (historicky podmieneného) uskutočňovania. Za výrazom „sloboda“ by sme mali hladat' konkrétne súbory praktík, umožňujúce menit' daný stav vecí - či už vo vzt'ahu $\mathrm{k}$ nám samým, alebo $\mathrm{k}$ druhým. To by znamenalo, že sloboda nie je určená ako stav rozhodovania a konania, ale skôr ako proces uskutočňovania zmeny, v ktorom sa „vlastné ja“ stáva, lebo sa môže stat' za pomoci vedomých praktík niekým iným. Slobodu charakterizuje nikdy nekončiaca práca na tejto zmene. ${ }^{8} \mathrm{~V}$ tomto kontexte by sme ju mohli označit' za ontologickú podmienku etiky a etiku za reflektovanú prax slobody - slobody jednotlivca (Foucault, 2000c, 135). ${ }^{9}$

\footnotetext{
${ }^{8}$ Foucault hovorí, že etické vymedzenie praktík slobody je preňho ovel’a dôležitejšie ako procesy oslobodzovania (Foucault, 2000c, 133 - 134).

${ }^{9} \mathrm{~V}$ tom istom rozhovore hovorí, že sloboda umožňuje vytvárat' mocenské vzt'ahy, bez ktorých by neexistovala možnost' odporu.
} 
V súvislosti s guvernmentalitou, ktorá v sebe zahŕňa okrem vedenia-moci aj oblast' subjektivácií, môžeme povedat', že sloboda (ako „sociálna prax“) je v našich spoločnostiach priamo zviazaná s umením vládnut', čo znamená, že uskutočňovanie slobody sa nezaobíde bez porozumenia racionalite, ktorá udržiava guvernmentalitu pri živote. Sloboda tkvie v praxi, v praktikách, ktoré vykonáva jednotlivec vo vzt’ahu $\mathrm{k}$ racionalite guvernmentality, ktorá riadi jeho správanie, ale nikdy ho nemôže ovládnut' tak, aby sa proti nej nemohol vzopriet' - čo v konečnom dôsledku môže viest' $\mathrm{k}$ vytvoreniu novej guvernmentality, ale nie $\mathrm{k}$ jej zrušeniu. Guvernmentalita je priam démonická sila, ak sa na ňu pozrieme z tohto uhla pohl'adu. Ale je to aj miesto odporu, pre ktorý sa môžeme rozhodnút', lebo sme slobodné bytosti.

\section{Literatúra}

BALANDIER, G. (1970): Political Anthropology. New York: Random House.

BRÖCKLING, U., KRASMANN, S., LEMKE, T. (eds.) (2011): Governmentality: Current Issues and Future Challenges. New York: Routledge.

BURAJ, I., PALENČÁROVÁ, S. (2015): Michel Foucault: Minulost' a súčasnost' (K niektorým otázkam sociálnej kontroly). Filozofia, 70 (7), 505 - 517.

BURAJ, I. (2010): Moc v štruktúre mocenských vzt’ahov. Filozofia, 65 (5), 417 - 427.

DEFERT, D. (1994): Chronologie. In: Defert, D. - Ewald, F. (eds.): Dits et écrits (1954 - 1988). Zv. I. Paris: Gallimard, $13-64$.

DELEUZE. G. (1996): Foucault. Prel. Č. Pelikán. Praha: Hermann a synové.

DESCOMBES, V. (1995): Stejné a jiné: čtyřicetpět let francouzské filosofie (1933-1978). Prel. M. Petř́íček. Praha: Oikúmené.

DREYFUS, H. L., RABINOW, P. (2010): Michel Foucault. Za hranicemi strukturalismu a hermeneutiky. Prel. J. Hasala, L. Nová, S. Polášek, P. Toman. Praha: Herrmann a synové.

FOUCAULT, M. (1972): Les intellectuels et le pouvoir (entretien avec G Deleuze). L'Arc, 49 (1), 3 - 10.

FOUCAULT, M. (1982): The Subject and Power. In: Dreyfus, H. L., Rabinow, P.: Michel Foucault: Beyond Structuralism and Hermeneutics. Chicago: The University of Chicago Press, 208 - 226.

FOUCAULT, M. (1985): Du pouvoir. In: Boncenne, P.: Écrire, lire et en parler. Paris: Robert Laffont, $355-363$.

FOUCAULT, M. (1989): Résumé des cours 1970 - 1982. Paris: Julliard.

FOUCAULT, M. (1991): Intelektuál a moc. In: Foucault, M.: Moc, subjekt a sexualita. Prel. M. Marcelli. Bratislava: Kalligram, $173-178$.

FOUCAULT, M. (1994a): Dits et écrits (1954-1988). Zv. I - IV. In: Defert, D. - Ewald, F. (eds.). Paris: Gallimard.

FOUCAULT, M. (1994b): Inutile de se soulever? In: Defert, D. - Ewald, F. (eds.): Foucault, M.: Dits et écrits (1954 - 1988). Zv. III. Paris: Gallimard, $790-794$.

FOUCAULT, M. (1994c): Structuralisme et poststructuralisme. In: Defert, D. - Ewald, F. (eds.): Dits et écrits (1954 - 1988). Zv. IV. Paris: Gallimard, 431 - 457.

FOUCAULT, M. (1994d): Table ronde du 20 mai 1978. In: Defert, D. - Ewald, F. (eds.): Dits et écrits (1954 - 1988). Zv. IV. Paris: Gallimard, $27-34$.

FOUCAULT, M. (1996): Omnes et singulatim. Ke kritice politického rozumu. In: Foucault, M.: Myšlení vnějšku. Praha: Herrmann a synové, 153 - 194.

FOUCAULT, M. (2000a): Dozerat' a trestat'. Zrod väzenia. Prel. M. Marcelli. Bratislava: Kalligram. FOUCAULT, M. (2000b): Estetika existencie. In: Foucault, M.: Moc, subjekt a sexualita. Prel. M. Marcelli. Bratislava: Kalligram, $155-160$. 
FOUCAULT, M. (2000c): Etika starostlivosti o seba samého ako prax slobody. In: Foucault, M.: Moc, subjekt a sexualita. Prel. M. Marcelli. Bratislava: Kalligram, $132-154$.

FOUCAULT, M. (2000d): Power. Essential Works of Foucault 1954 - 1984, zv. 3. Faubion, J. D. (ed.). New York: The New Press.

FOUCAULT, M. (2000e): Priestor, vedenie a moc. In: Foucault, M.: Moc, subjekt a sexualita. Prel. M. Marcelli. Bratislava: Kalligram, $27-43$.

FOUCAULT, M. (2000f): Starost' o pravdu. In: Foucault, M.: Moc, subjekt a sexualita. Články a rozhovory. Prel. M. Marcelli. Bratislava: Kalligram, $108-119$.

FOUCAULT, M. (2000g): Štrukturalizmus a postštrukturalizmus. In: Foucault, M.: Moc, subjekt a sexualita. Prel. M. Marcelli. Bratislava: Kalligram, $44-72$.

FOUCAULT, M. (2000h): Technológie seba samého. In: Foucault, M.: Moc, subjekt a sexualita. Prel. M. Marcelli. Bratislava: Kalligram, 186 - 214.

FOUCAULT, M. (2001): L'Herméneutique du sujet. Cours au Collège de France, 1981 - 1982. F. Gros (ed.). Paris: Seuil.

FOUCAULT, M. (2003): Uživání slastí. Dějiny sexuality II. Prel. K. Thein, N. Darnadyová a J. Fulka. Praha: Herrmann a synové.

FOUCAULT, M. (2004a): Naissance de la biopolitique. Cours au Collège de France, 1978 - 1979. Paris: Gallimard / Seuil.

FOUCAULT, M. (2004b): Sécurité, territoire, population. Cours au Collège de France, 1977 1978. Paris: Gallimard / Seuil.

FOUCAULT, M. (2005): Je třeba bránit společnost. Prel. P. Horák. Praha: Filosofia.

FOUCAULT, M. (2012): Du Gouvernement des vivants. Cours au Collège de France, 1979 - 1980. Paris: Seuil.

FOUCAULT, M. (2016): About the Beginning of the Hermeneutics of the Self: Lectures at Darmounth College, 1980. Chicago: The University of Chicago Press.

GORDON, C. (1991): Governmental rationality: An introduction. In: Burchell, G. - Gordon, C. Miller, P. (eds.): The Foucault Effect: Studies in Governmentality. With Two Lectures by and an Interview with Michel Foucault. Chicago: University of Chicago Press, $1-51$.

JESSOP, B. (2007): From micro-powers to governmentality: Foucault's work on statehood, state formation, statecraft and state power. Political Geography, 26 (1), 34 - 40. DOI: https://doi.org/10.1016/j.polgeo.2006.08.002

LAMPE, K. (2015): Rethinking Aeschines of Sphettus. In: Zilioli, U. (ed.): From the Socratics to the Socratic Schools. New York - London: Routledge Press, $61-81$.

PERROT, M. (ed.) (1980): L'impossible prison: Recherches sur Ie système pènitentiare au XIXe siecle. Paris: Éditions du Seuil.

PROZOROV, S. (2007): Foucault, Freedom and Sovereignty. Hampshire: Ashgate Publishing.

REVEL, J. (2002): Le vocabulaire de Foucault. Paris: Ellipses.

Štúdia je súčast’ou riešenia grantovej úlohy VEGA 1/0094/20.

Vladislav Suvák

Inštitút filozofie

Filozofická fakulta PU v Prešove

17. novembra 1

08001 Prešov

Slovenská republika

e-mail: vladislav.suvak@gmail.com

ORCID: https://orcid.org/0000-0003-3067-9870 